\title{
Common abbreviations
}

$\begin{array}{ll}\text { AIDS } & \text { Acquired Immune Deficiency Syndrome } \\ \text { ECLA } & \text { Economic Commission for Latin America } \\ \text { EEC } & \text { European Economic Community } \\ \text { EU } & \text { European Union } \\ \text { FAO } & \text { Food and Agriculture Organisation } \\ \text { FDI } & \text { Foreign Direct Investment } \\ \text { GATT } & \text { General Agreement on Tariffs and Trade } \\ \text { GDP } & \text { Gross Domestic Product } \\ \text { GNP } & \text { Gross National Product } \\ \text { HDI } & \text { Human Development Index } \\ \text { HIPCs } & \text { Heavily Indebted Poor Countries } \\ \text { HIV } & \text { Human Immunodeficiency Virus } \\ \text { IBRD } & \text { International Bank for Reconstruction and Development } \\ \text { ILO } & \text { International Labour Organization } \\ \text { IMF } & \text { International Monetary Fund } \\ \text { ISI } & \text { Import Substitution Industrialisation } \\ \text { LDCs } & \text { Less Developed Countries } \\ \text { MDGs } & \text { Millennium Development Goals } \\ \text { MNCs } & \text { Multi National Corporations } \\ \text { NGOs } & \text { Non Governmental Organisations } \\ \text { NICs } & \text { Newly Industrialised Countries } \\ \text { NNP } & \text { Net National Product } \\ \text { ODA } & \text { Official Development Assistance } \\ \text { OECD } & \text { Organisation for Economic Cooperation and Development } \\ \text { OPEC } & \text { Organisation of Petroleum Exporting Countries } \\ \text { PPP } & \text { Purchasing Power Parity } \\ \text { PRSP } & \text { Poverty Reduction Strategy Papers } \\ \text { R\&D } & \text { Research and Development } \\ \text { TNCs } & \text { Transnational Corporations } \\ \text { UN } & \text { United Nations } \\ \text { UNCTAD } & \text { United Nations Conference on Trade and Development } \\ \text { UNDP } & \text { United Nations Development Programme } \\ \text { UNESCO } & \text { United Nations Educational, Scientific and Cultural Organization } \\ \text { UNICEF } & \text { United Nations Children's Fund } \\ \text { UNIDO } & \text { United Nations Industrial Development Organization } \\ \text { WHO } & \text { World Health Organization } \\ \text { WTO } & \text { World Trade Organization } \\ & \end{array}$

